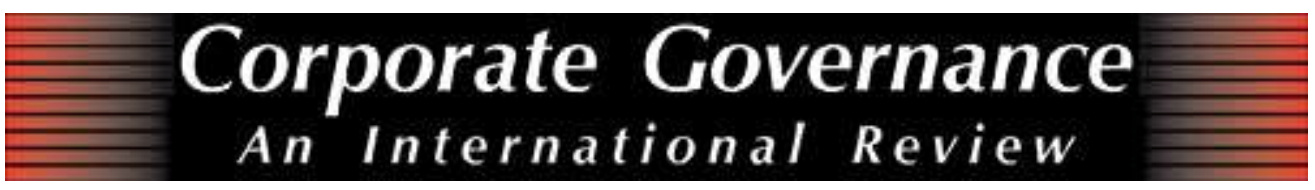

\title{
Boards of Directors' Contribution to Strategy: A Literature Review and Research Agenda
}

\begin{tabular}{|r|l|}
\hline Journal: & Corporate Governance: An International Review \\
\hline Manuscript ID: & CGIR-2008-0275RI.R2 \\
\hline Manuscript Type: & Review Issue \\
\hline Keywords: & $\begin{array}{l}\text { Business Policy \& Strategy < Board Policy issues, Internal CG: } \\
\text { Board of directors issues, Board Policy issues, Governance Theories }\end{array}$ \\
\hline
\end{tabular}

\section{ScholarONE \\ Manuscript Central}




\title{
Boards of Directors' Contribution to Strategy: A Literature Review and Research Agenda
}

\begin{abstract}
Manuscript Type: Literature review.

Research Question/Issue: Over the last four decades, research on the relationship between boards of directors and strategy has proliferated. Yet to date there is little theoretical and empirical agreement regarding the question of how boards of directors contribute to strategy. This review assesses the extant literature by highlighting emerging trends and identifying several avenues for future research.

Research Findings/Insights: Using a content-analysis of 150 articles published in 23 management journals until 2007, we describe and analyze how research on boards of directors and strategy has evolved over time. We illustrate how topics, theories, settings and sources of data interact and influence insights about board-strategy relationships during three specific periods.

Theoretical/Academic Implications: Our study illustrates that research on boards of directors and strategy evolved from normative and structural approaches to behavioral and cognitive approaches. Our results encourage future studies (i) to examine the impact of institutional and context-specific factors on the (expected) contribution of boards to strategy, and (ii) to apply alternative methods to fully capture the impact of board processes and dynamics on strategymaking.

Practical/Policy Implications: The increasing interest in boards of directors' contribution to strategy echoes a movement towards more strategic involvement of boards of directors. However, best governance practices and the emphasis on board independence and control may hinder the board contribution to the strategic decision-making. Our study invites investors and policymakers to consider the requirements for an effective strategic task when they nominee board members and develop new regulations.
\end{abstract}




\section{INTRODUCTION}

Over the last few decades, corporate governance systems have undergone profound changes worldwide. The globalization and liberalization of financial markets, corporate governance scandals and stronger demands for accountability and transparency have placed the duties and functioning of boards of directors at the centre of the corporate governance debate (Kiel and Nicholson, 2003; Ingley and Van der Walt, 2005). The societal call for an increasing involvement of the board of directors has raised the question what the appropriate role of boards should be. While scholars and practitioners have generally acknowledged the importance of adequate board control and independence (Baysinger and Hoskisson, 1990; Jensen and Zajac, 2004), boards' involvement in their strategic role, or the lack thereof, has been widely debated (Zahra and Pearce, 1989; Golden and Zajac, 2001; Daily, Dalton and Cannella, 2003).

The discussion on boards' strategic involvement has been fueled by a combination of contextual factors, alternate theoretical perspectives and inconclusive empirical results. First, in the 1970s, it was observed that US boards of directors had been rather passive in the wake of corporate failures and more strategic involvement was necessary to restore the public confidence (Clendenin, 1972; Heller and Milton, 1972; Mace, 1976; Machin and Wilson, 1979; Vance, 1979). More recently, corporate governance reforms (Aguilera and Cuervo-Cazurra, 2004; Enrione, Mazza and Zerboni, 2006; Sheridan, Jones and Marston, 2006) and the increasing influence of institutional investors may have brought board members closer to strategic decisionmaking (Judge and Zeithaml, 1992; Hoskisson, Hitt, Johnson and Grossman, 2002). These developments have stimulated boards of directors to challenge CEOs, and to become more involved in strategy, an area that in the past was exclusively controlled by CEOs (Ruigrok, Peck and Keller, 2006; Monks and Minow, 2008). Second, the emergence of alternative, partially conflicting theoretical viewpoints have contributed to the debate. Theories, such as agency 
theory, resource dependency theory and stewardship theory, have ascribed different responsibilities to boards with regard to strategy (Davis, 1991; Maassen and Van Den Bosch, 1999). Third, while studies suggest that board members are becoming more aware of their strategy role (Demb and Neubaurer, 1992; Heracleous, 2001; Huse, 2005), scholars have regularly highlighted the disagreement in the empirical research on the relationship between boards and strategy (Johnson, Daily and Ellstrand, 1996; Deutsch, 2005).

The above theoretical pluralism and empirical inconclusiveness in the literature on boards of directors and strategy raises the following questions: what is the stance of research in this area? How has the field been evolving over time? And what are the main challenges and future opportunities? In this paper we analyze 150 articles on boards and strategy published in 23 management journals until 2007, in order to provide answers to these questions. Thereby, this paper contributes to the literature on boards and strategy in three ways. First, it describes how studies on boards and strategy have been evolving and illustrates how certain topics, theories, settings and sources of data interact and have influenced our knowledge about board-strategy relationships during certain periods. For instance, our data reveal that during the 1990s the field was dominated by empirical studies in a US setting that mainly refer to agency theory and focus on the determinants and consequences of boards' strategic involvement. Second, the paper complements previous literature reviews that have (partially) covered this domain (Zahra and Pearce, 1989; Johnson et al., 1996; Deutsch, 2005). Given the time elapsed since these reviews, the intensification of the corporate governance debate internationally and the large number of studies conducted on boards of directors and strategy more recently, it is the right time for due reflection on achievements in this area (Huse, 2005). Third, the paper highlights several avenues to advance the field of study. Our findings encourage governance scholars to further investigate the impact of contextual forces at multiple levels, to further comprehend board processes and 
dynamics, and to adopt methods aimed at opening the black box of board research. Finally, the article has implications for practice. Existing board practices emphasize, in fact, board control and independence as antecedents of good governance, but these aspects may also hinder the board's contribution to strategy-making. In line with some recent works, our study suggests that the requirements for an effective strategic task should be taken into account while composing boards and devising new regulations.

The paper is structured as follows: section one describes the basics of the board-strategy debate and the theoretical pluralism and empirical inconclusiveness emerging from the literature on boards and strategy. Section two describes the research method, i.e., how we selected journals and determined our sample of 150 articles to be included in our review, how we coded the content of each article and how data were analyzed statistically. Next, in section three we present the results of our review, describe how the field has evolved and illustrate how certain topics, theories, settings and sources of data interact and have dominated in certain time periods. In our final section, we discuss the implications for both theory and practice and present a research agenda for future studies on boards and strategy.

\section{THEORETICAL AND EMPIRICAL DEBATE ON BOARDS AND STRATEGY}

The appropriate role of the board of directors in formulating and implementing strategy has been long debated (Andrews 1981a, 1981b; Judge and Zeithaml, 1992; McNulty and Pettigrew, 1999; Useem, 2003). While the literature has acknowledged the importance and need for adequate board control and independence (Baysinger and Hoskisson, 1990; Jensen and Zajac, 2004), both the contributions of boards to strategy and the desirability of such practice have remained topics of discussion (Golden and Zajac, 2001; Daily et al., 2003). In light of a multitude of theoretical lenses and empirical findings in the management literature, Zahra and Pearce's observation that 
'there is controversy over the nature of directors' strategic role' (1989: 328) still seems to be topical after twenty years of research.

The debate on boards' strategic contribution dates as far back as the 1970s. During this decade, several US scholars and practitioners observed that boards were rather passive in the wake of US corporate failures and that more strategic involvement was necessary to restore public confidence (Clendenin, 1972; Mace, 1976; Vance, 1979). A growing theoretical debate was boosted by Fama and Jensen's seminal work (1983) in which they distinguished decision management, i.e. initiating and implementing (strategic) decisions, and decision control, i.e. ratifying and monitoring (strategic) actions. The two tasks were ascribed to the top management team and the board of directors respectively. Their rationale has influenced the debate ever since. By relying on a clear distinction of responsibilities between boards and management, scholars have viewed the potential contributions of boards to strategy as fairly limited due to their distance from day-to-day operations, the presence of information asymmetries and the need to remain independent (Conger, Lawler and Finegold, 2001; Hendry and Kiel, 2004; Charan, 2005). Instead, others have argued that boards of directors are legally responsible for the strategy of firms (Harrison, 1987; Coffee, 2005; Yawson, 2006) and that boards are in an excellent position to contribute to strategy (Andrews, 1980; Tricker, 1984; Goodstein, Gautum and Boeker, 1994; Carpenter and Westphal, 2001).

\section{Theoretical Pluralism in the Board-Strategy Debate}

From a theoretical standpoint, the debate around board strategic involvement has been fueled by conflict and consensus theories (Davis, 1991; Muth and Donaldson, 1998; Maassen and Van Den Bosch, 1999). A conflict perspective conceptualizes managers as self-interested agents that should be closely monitored (Jensen and Meckling, 1976; Eisenhardt, 1989). For instance, agency 
theory posits that boards affect strategic choices by preventing managers from acting opportunistically at the expense of shareholders (Mizruchi, 1983). In this view, boards are not expected to initiate and implement strategies, but they contribute through ratifying and monitoring strategic decisions (Fama and Jensen, 1983; Goodstein et al., 1994). Board involvement in strategy appears to conflict with this view, as (i) it would make boards of directors co-responsible for strategic decisions and (ii) it would jeopardize the required distance between board members and managers (Boyd, 1990, 1994; Huse, 1994; Sundaramurthy and Lewis, 2003).

A consensus perspective conceptualizes managers as intrinsically motivated agents acting in the best interest of the firm (Davis, Schoorman and Donaldson, 1997). Accordingly, through various theoretical lenses boards are defined as organizational bodies that may support empowered managers in strategy formulation and implementation (Bezemer, Maassen, Van den Bosch and Volberda, 2007; Huse, 2007). For example, resource dependency theory suggests that board members are in an excellent position to contribute to (strategic) decision-making by providing access to resources on which firms depend (Pfeffer, 1972, 1973; Pfeffer and Salancik, 1978; Hillman and Dalziel, 2003). The stewardship theory challenges the rationale of agency theory by arguing that the interests of managers and board members do not necessarily collide (Davis et al., 1997; Muth and Donaldson, 1998). In this perspective, the role of boards is to facilitate and empower managers, also in the realm of strategy. More lately, cognitive and behavioral approaches have emphasized the importance of understanding cognitive contributions of board members as well as the impact of boardroom dynamics on strategic decision-making (Pettigrew, 1992; McNulty and Pettigrew, 1999; Rindova, 1999; Pye and Camm, 2003).

\section{Empirical Inconclusiveness in the Board-Strategy Debate}


Aside to the theoretical debate, empirical findings provide mixed results as well. In recent decades scholars have regularly emphasized the presence of a wealth of inconclusive empirical findings (Deutsch, 2005). On the one hand, studies have shown that boards have been rather passive and subject to CEOs and executives' dominance (Mace, 1971; Herman, 1981; Kosnik, 1987; Lorsch and McIver, 1989). Furthermore, anecdotal evidence suggests that boards might destroy value when they become involved in strategy (cf. Jensen, 1993; Fulghieri and Hodrick, 2006; Hitt, Harrison and Ireland, 2006). On the other hand, scholars have shown that boards are becoming more actively involved in strategy (Zahra, 1990; Zahra and Filatotchev, 2004; Ingley and van der Walt, 2005; Ravasi and Zattoni, 2006; Schmidt and Bauer, 2006). Moreover, boards have affected important elements of strategies, such as the scope of the firm (Tihanyi, Johnson, Hoskisson and Hitt, 2003; Jensen and Zajac, 2004), entrepreneurship and innovation (Fried, Burton and Hisrich, 1998; Zahra, Neubaum and Huse, 2000; Hoskisson et al., 2002), strategic change (Johnson, Hoskisson and Hitt, 1993; Westphal and Fredrickson, 2001; Filatotchev and Toms, 2003), R\&D strategies (Baysinger, Kosnik and Turk, 1991; Kor, 2006) and internationalization (Sanders and Carpenter, 1998; Datta, Rajagopalan and Zhang, 2003).

In sum, the literature on boards of directors and strategy may be characterized by theoretical pluralism and by empirical inconclusiveness, both originating from scholarly contributions and anecdotal evidence. In the remainder of this paper, we seek to highlight how distinct patterns of research have emerged over the years and their key attributes.

\section{METHOD}

\section{Selection of Journals and Papers}

To examine the evolving literature on boards and strategy, we decided to focus on peer-reviewed studies published in management journals, regardless of their impact factor (Seglen, 1994). We 
selected all journals included in the management category within the ISI-Web of Knowledge during 2007. Our search produced 81 records in total. In the next phase, we used the databases ABI/Inform, Business Source Premier, Ebsco-Host, JSTOR and Swetsnet to search for all paper publications containing simultaneously the terms 'board' and 'strateg*' or 'director' and 'strateg*' in the title, abstract and/or key words. This approach enabled us to identify a set of articles directly referring to the debate on boards' and directors' contribution to strategy. This procedure resulted in 371 hits in total: 150 papers $(40.4 \%)$ turned out to be relevant to our examination. The large difference between the number of hits and the number of included papers is due to several factors. We excluded papers referring to board games, papers using the term across-the-board, fictive Harvard cases, letters from editors, book reviews, papers referring to organizations with the term 'board' in their name and papers referring to other management layers than the board of directors. In sum, our final sample consists of 150 articles published in 23 journals from 1972 (first included paper) until 2007.

\section{Content Analysis}

In order to analyze the evolving nature of studies on boards of directors and strategy, two raters have independently analyzed and coded the set of 150 articles (Coffey and Atkinson, 1996; Krippendorf, 2005). The two raters were asked to codify all basic elements of a paper: (i) type of article, (ii) main research topic, (iii) use of theories, (iv) research setting, (v) source of data and (vi) the definition of board strategic involvement (Insch, Moore and Murphy, 1997). The coding scheme was pre-tested on two sub-samples of 30 articles after which the raters came to an agreement about the final set of items to be used in the classification for each category. A review was then conducted on the whole set of articles (D'Aveni and McMillan, 1994). At the end of the coding procedure, the two sets of data were matched. There appeared to be a high overlap in the 
responses: only 54 out of 828 items were coded differently by the two raters. Inter-rater reliability scores were calculated and the percent agreement (93.5\%) and Cohen's Kappa (0.916) were both above the acceptance threshold (Cohen, 1960; Dewey, 1983). A final meeting was arranged to discuss the 54 inconsistencies in the responses. To reconcile the disagreements, the articles were re-read and recoded. If the raters still did not agree on the coding, a senior strategy professor who was involved in the research project - was asked to provide a clarifying interpretation (Lee, 1999). In the following sections we will discuss all categories in more detail.

(i) Type of article. The 150 articles were differentiated according to their nature: 'conceptual' versus 'empirical'. Papers were coded 'conceptual' when they aimed to advance or refine theory and were solely based on deductive reasoning without any empirical metrics. Papers were labeled 'empirical' if authors applied inductive logics, described their methods in a separate section and argued on the strength of data obtained from qualitative research methods (i.e. interviews, participant observation and anecdotes) and/or quantitative methods (i.e. archival data and surveys).

(ii) Main research topic. Building upon prior studies (e.g. Zahra and Pearce, 1989; Pearce and Zahra, 1992; Stiles, 2001; Huse, 2005) we distinguished four groups of papers in relation to the main research topic. The first group examines the determinants of board strategic involvement. Among others, scholars have sought to relate environmental characteristics, ownership structure, board composition and incentive mechanisms to various levels of board strategic involvement. The second group of studies investigates the consequences of board strategic involvement. For instance, scholars have addressed the impact of specific board characteristics on strategic outcomes, such as diversification, internationalization, innovation and strategic change. The third group of papers explores boards' participation in strategic decisionmaking processes, i.e., the ways in which boards contribute internally to decision making 
processes by interacting with TMTs in various phases. Finally, the fourth group of papers discusses from a normative stance why board strategic involvement may or may not be desirable. Topics of debate include the reasons for the perceived passivity of boards of directors in this respect and the question how far board involvement into strategy should be going.

(iii) Use of theories. To examine the theoretical development of the field, we mapped to which theories each paper explicitly referred. Given the widespread application of agency theory in the literature on boards and strategy, we decided to create a variable capturing whether a paper referred to: (i) agency theory solely; (ii) multiple theories, including agency theory and (iii) other theories than agency theory or no theory.

(iv) Research Setting. As highlighted by comparative corporate governance studies highlight, institutional contexts widely vary between nations and have a profound impact on local corporate governance structures and practices (Aguilera and Cuervo-Cazurra, 2004; Aguilera, Filatotchev, Gospel and Jackson, 2008; Zattoni and Cuomo, 2008). Therefore an important dimension to our analysis is added by examining the empirical setting in which research on boards and strategy has been conducted. As most empirical articles in our sample are based on US data, we decided to use the following categorization: (i) articles using exclusively data drawn from the US; (ii) articles using data from multiple-countries, including the US and (iii) articles using data drawn from a non-US context.

(v) Source of data. To provide insights in the use of different data sources, we coded the empirical articles with the following six categories: i) interviews, ii) anecdotal evidence, iii) archival data, iv) survey data, v) direct observations and vi) combinations of the above-mentioned sources. In the latter category we only included articles using combinations of interviews and survey data, interviews and archival data, and survey data and archival data. 
(vi) Definition of board strategic involvement. Board strategic involvement is a latent construct and no single way to define or interpret it emerges from literature (Ravasi and Zattoni, 2006). Building upon prior studies (Zahra and Pearce, 1990; 1992; Judge and Zeithaml, 1992; McNulty and Pettigrew, 1999), we distinguished four broad categories to classify the definition of board strategic involvement. The first category includes studies assessing how boards of directors impact on the general strategy of companies. For example, by developing the mission, establishing long-term targets and allocating resources (Zahra and Pearce, 1990; Volberda, Baden-Fuller and Van den Bosch, 2001). The second group of papers investigates how boards contribute to specific strategic outcomes. The majority of papers in this category are input-output studies that aim to identify how board composition affects strategic outcomes, such as innovation, change, diversification, and mergers and acquisitions (Johnson et al., 1996). The third group encompasses research that explores how boards participate in various phases of strategic decision-making through interacting with TMTs. Among others, the studies conducted by Judge and Dobbins (1993), Forbes and Milliken (1999) and Rindova (1999) are included in this category. Finally, the fourth category consists of papers in which the nature of board strategic involvement is not clearly stated and defined. Most papers published in the 1970s and 80's fit into this category, as the concept of board strategic involvement was in general marginally defined in the early years.

\section{EMPIRICAL RESULTS}

\section{Growing Attention to Research on Boards and Strategy}

In recent decades, scholars and practitioners have debated the relationship between the boards of directors and strategy. Figure 1 illustrates the historical development of the number of published articles explicitly referring to boards and strategy in the management literature. As depicted, the 
first paper was published in 1972 and in the following decades the number of published articles steadily increased. Studies on boards and strategy were published irregularly during the early years, prior to the publication of Zahra and Pearce's study in 1989. Since then, the marked increase in the average number of articles on the topic has reflected the growing attention of scholars in the field of strategy and governance (from 1.3 in the period 1972-1989 to 9.6 in the period 2001-2007). Also in relative terms the space devoted to studies on boards of directors and strategy has increased: from 0.1 articles per management journal per year in the period 19721989 to 0.4 articles in the period 2001-2007. Finally, it is noteworthy that in the period 19721989 most papers were published in general, applied practice-oriented journals such as the Long Range Planning (8), California Management Review (6) and Harvard Business Review (5). Since 1990 two specialized journals in strategy and corporate governance, Corporate Governance: An International Review (24) and Strategic Management Journal (14), have contributed the most (see figure 2).

Insert Figures 1 and 2

\section{Descriptives and Interactions of Topics, Theories, Settings and Data Sources}

Figure 3 provides an overview of the characteristics of the articles that have contributed to the growing attention in boards of directors and strategy. The papers are overwhelmingly empirical $(\mathrm{n}=114 ; 76 \%)$. Most empirical studies have been conducted in the USA $(n=72 ; 62 \%)$ or in multiple settings including the USA $(n=5 ; 4 \%)$. With regard to the main research topic, most articles have contributed to the debate on the desirability of board strategic involvement $(\mathrm{n}=41$; $27 \%$ ), although the overall sample is distributed evenly across all categories. In terms of use of theories, agency theory is the prevailing lens $(n=63 ; 42 \%)$ : it has been used as the sole 
theoretical lens $(n=27 ; 18 \%)$ and in combination with other theoretical lenses $(n=36 ; 24 \%)$. The sources of data are quite diverse, although the use of archival data $(n=45 ; 40 \%)$ and of multiple sources $(n=22 ; 19 \%)$ is most common. Finally, the largest group of studies defines board strategic involvement in terms of boards' contributions to specific strategic outcomes $(n=52 ; 35 \%)$, while the smallest group defines it as boards' participation to strategic decision-making $(\mathrm{n}=22 ; 15 \%)$.

Insert Figure 3

Furthermore, figure 3 illustrates how topics, theories, settings and data sources interact. Most notable are the key differences between empirical studies that have been conducted in a US context and those conducted in a non-US context. In the US context scholars have published most on the determinants $(n=26 ; 36 \%)$ and consequences of board strategic involvement $(n=21 ; 29 \%)$. Furthermore, these studies refer to agency theory in most instances $(n=38 ; 53 \%)$ and mainly use archival data $(n=39 ; 54 \%)$. Finally, board strategic involvement has generally been defined as the contribution of boards to specific strategic outcomes, such as innovation, strategic change and mergers and acquisitions $(n=37 ; 51 \%)$. In contrast, studies conducted in a non-US context most often examine the participation in strategic decision-making by boards $(\mathrm{n}=14 ; 38 \%)$. Furthermore, these studies often refer to alternative theoretical lenses $(n=25 ; 68 \%)$ and use qualitative methods, such as interviews $(\mathrm{n}=10 ; 27 \%)$ and direct observations $(\mathrm{n}=5 ; 14 \%)$ more often. Finally, these studies differ in their definition of board strategic involvement, i.e., all categories are evenly represented. Theoretical papers differ from both types of empirical papers. These papers generally address the practice and question the desirability of boards' strategic involvement $(\mathrm{n}=19 ; 53 \%)$, show a limited reference to agency theory $(\mathrm{n}=13 ; 36 \%)$ and the 
definition of board strategic involvement is in most instances rather unspecified $(n=17 ; 47 \%)$. We tested the above-mentioned interactions for statistical significance. Several cross tabulations reveal that the relationships between the main research topic, use of theories, research setting and the definition of board strategic involvement are indeed statistically significant at the 0.05-level.

\section{Three Distinct Research Periods}

In order to observe an evolutionary pattern in previous research, we identified three periods and assigned each article to one of them according to the year of publication. Even though the three windows are not homogeneous in terms of time-length, we clustered them in accordance with two criteria. First, we observed changes in the slope of the curve with cumulative number of articles published over time (see figure 1). We considered a cut-off for a 'new period' if (i) there was a sharp increase in the number of publications in a given year and if (ii) this number was significantly higher than the average during the previous years. Second, we identified a 'new period' if relevant and highly influential articles (or groups of articles) came out during a given year or the year before. Major changes in a field of study often occur thanks to breakthrough and innovative articles that suggest new theoretical approaches and/or methods and set a new agenda for future research (Kuhn, 1962). We checked for robustness by examining whether our findings would change if we slightly changed our cut-off points. Although our results became less significant, overall the witnessed developments proved to be robust.

Our first observation window covers the period from the first publication (1972) until Zahra and Pearce's literature review in 1989. In this period, the interest in studies on boards and strategy seems to be infrequent and concentrated around the years 1972, 1979 and 1986. In 1990, one year after Zahra and Pearce's literature review, six papers on the topic were published, i.e. Baysinger and Hoskisson (1990), Boyd (1990), Hoskisson and Turk (1990), Kosnik (1990), Lang 
and Lockhart (1990) and Zahra (1990). These papers provided input to a new strand of research and most of the literature in the following years sought to analyze the relationship between board composition and strategic outcomes. Our second observation window ends in 2000. In 1999 and 2000 great interest around boards and strategy arouse, as 17 articles were published in the two years. During this period an alternate stream of literature came out with a new perspective on boards' roles and behavior (Dalton, Daily, Ellstrand and Johnson, 1998; Forbes and Milliken, 1999; Gulati and Westphal, 1999; McNulty and Pettigrew, 1999; Rindova, 1999; Hillman, Canella and Paetzold, 2000). These researchers had a significant impact on the field and fueled the debate around cognitive and behavioral approaches. In the following sections, we will discuss the distinctive characteristics of articles published during each period (see figures 4 and 5).

Insert Figures 4 and 5

Period 1 (1972-1989): The emerging debate about boards' strategic involvement

The early literature explicitly referring to boards and strategy dates back to the beginning of the 1970s. At that time, the debate was mostly driven by the practical needs that the US business community was facing. Corporate failures and governance scandals together with the increasing requirements for higher accountability fueled studies on boards and governance issues (Vance, 1979; Lorsch, 1986). At the same time, strategy started to become established as research field (Volberda and Elfring, 2001), fueled by major changes in the business environment of most Western countries (i.e. the increase in Japanese competition and the oil crisis) (Pettigrew, Thomas and Whittington, 2002). During this first period, research on boards and strategy was characterized by a debate on the desirability of active board involvement, also in the realm of 
strategy. This discussion followed an ongoing US debate around a perceived passivity of boards of directors at that time (Mace, 1971; Herman, 1981; Stiles and Taylor, 2002). The ongoing debate has been hosted mainly by three general, applied practice-oriented journals (i.e. Long Range Planning, California Management Review and Harvard Business Review) that covered almost $80 \%$ of the studies in this period (see figure 2). Regardless of the type of articles, both conceptual and empirical articles have generally sought to initiate a discussion around the desirability of boards' involvement in strategy (67\%).

Overall, two strands of research with opposite views on the topic can be distinguished during this period. On the one hand, boards were considered one of the main actors in strategic decision-making processes, though they are not expected to formulate strategy. For instance, Andrews $(1980 ; 1981 a)$ emphasized that boards are in a perfect position to search for alternative corporate strategies. Furthermore, Felton (1979) argued that boards should confront management in case where results deviate from expectations, also in the realm of strategy. To support adequate fulfillment of the strategy role, Wommack (1979 and Harrison (1987) suggest that boards should create an internal board committee dedicated to this issue. On the other hand, another group of scholars strongly argued that boards should not be actively involved in strategy. For instance, according to Heller and Milton (1972) strategic issues are a difficult subject for directors to get into, as they are often not involved in the company on a daily basis. Moreover, Mace (1976) argues that outside directors are mostly hired through cooptation or hold board positions elsewhere; this practice may limit their commitment and involvement in strategic issues. Finally Rosenstein (1987) describes several hurdles that directors may face when they try to get involved in strategy.

In sum, the key characteristics of research during this period are (i) the lack of one prevailing theory, (ii) the predominance of articles discussing the desirability of board strategic 
involvement (67\%) and (iii) a broadly defined concept of board strategic involvement in most instances (79\%). Therefore, it comes as no surprise that Zahra and Pearce, at the end of this period, assert that "overall, empirical research on the boards' strategic role is in its infancy stage" (1989:304).

\section{Period 2 (1990-2000): The heyday of 'input-output approaches'}

Two breakthrough articles influenced the emerging literature on boards of directors and strategy at the beginning of the 1990s. Zahra and Pearce's (1989) literature review highlighted the importance of understanding the relationship between board characteristics and structure, and strategy. Additionally, Baysinger and Hoskisson (1990) discussed the prominence of board-TMT dynamics and its implications for strategy. Furthermore, they emphasized also that 'evaluating the strategic implications of boards of directors requires empirical analysis' (1990:73). Following these suggestions, multiple studies were published during the next decade. Generally, they relate board characteristics and structure (i.e. board size, CEO-duality, board diversity, outsider ratio, tenure and directors' equity stakes) to strategic outcomes, such as acquisitions (Haunschild, 1993; Hayward and Hambrick, 1997; Haunschild and Beckman, 1998) strategic change (Goodstein and Boeker, 1992; Goodstein et al., 1994; Bergh, 1995), corporate restructuring (Sheppard, 1994; Daily, 1995), entrepreneurship (Zahra, 1996), internationalization (Sanders and Carpenter, 1998) and R\&D expenditures (Baysinger et al., 1991). Generally, these studies provide mixed evidence of relationships between board characteristics and strategy (Daily et al., 2003; Deutsch, 2005).

Illustrative of this line of inquiry is that the majority of studies (i) refers to agency theory (54\%), (ii) uses US samples (86\%), (iii) analyzes archival data (49\%) and (iv) was published in the journals Academy of Management Journal, Administrative Science Quarterly and Strategic 
Management Journal (37.3\%) (see figure 2). Interestingly, two different lines of inquiry started to develop as well. One group examined the antecedents of board strategic involvement (Zahra, 1990; Zahra and Pearce, 1990; Judge and Zeithaml, 1992; Fried et al., 1998). A second group investigated the effects of the relationship between board and TMTs on strategic decision-making (Bradshaw-Camball and Murray, 1991; Judge and Dobbins, 1993; Fried and Hisrich, 1995; Westphal, 1998; Gulati and Westphal, 1999). At the end of the 1990s, contributions by Forbes and Milliken (1999), McNulty and Pettigrew (1999) and Rindova (1999) opened up the debate on boards' contribution to strategy processes and led to a new stream of research in this area.

\section{Period 3 (2001-2007): Towards more pluralism in the board-strategy debate}

As witnessed by the sharp increase in the average number of papers published each year (9.6), research on boards and strategy gained even more momentum during this period. These years are characterized by the co-existence of different research approaches. Most studies still focus on the determinants and consequences of board strategic involvement (47\%), use archival data (36\%) in a US setting (49\%) and extensively refer to agency theory (42\%). At the same time, studies with different features emerged in this period. First, empirical studies drawing on non-US data become more frequent. For example, the corporate governance contexts of Australia (Bonn and Fisher, 2005), Belgium (Van den Heuvel, Van Gils and Voordeckers, 2005), Italy (Zona and Zattoni, 2007), Japan (Yoshikawa and Phan, 2005), New Zealand (Ingley and Van der Walt, 2005), Norway (Huse, Minichilli and Shoning, 2005) and the United Kingdom (Long, Dulewicz and Gay, 2005; Yawson, 2006) were examined. Second, new theoretical standpoints have been used to interpret phenomena (Hendry and Kiel, 2004; Keenan, 2004) and most of the published articles do not refer to agency theory, but to alternate theoretical lenses (58\%). 
Building upon earlier contributions by Forbes and Milliken (1999), McNulty and Pettigrew (1999) and Rindova (1999), research on boards and strategy is also characterized by the emergence of behavioral and cognitive approaches also. Studies in this tradition aim to understand how boards participate in strategic decision-making as an active part of it (Stiles and Taylor, 1996). Based on this approach, Jensen and Zajac (2004) and Useem and Zelleke (2006) highlight that boards participate in these processes through continuously interacting with managers and/or other stakeholders. Moreover, Rindova (1999) and Fiegener (2005) argue that board of directors' work is not limited to ratification and monitoring only (cf. Fama and Jensen, 1983): boards of directors should rather be involved in all phases. Furthermore, Mueller, Sillince, Harvey and Howorth (2003) underline the conflicting requirements boards of directors face in fulfilling the monitoring role (independence) and the strategy role (involvement). Scholars have also started to investigate the joint impact of board dynamics, working style and structure on strategic issues (Golden and Zajac, 2001; Huse, 2005), as well as how the expertise, abilities and network ties of board members affect their ability and motivation to contribute to strategy formulation (Carpenter and Westphal, 2001; Roberts, 2002; Hillman, 2005) and the board of directors' overall capacity to impact on CEOs and TMTs (Westphal and Frederickson, 2001; Arthaud-Day, Certo, Dalton and Dalton, 2006; Grossman and Cannella, 2006).

\section{DISCUSSION}

Over the last four decades, the interest in research on the relationship between boards of directors and strategy has grown significantly (see figure 1). Scholars and practitioners have extensively discussed the potential contribution of boards as well as the (un)desirability of active boards in this domain. Witnessing pluralism and controversy in the literature on boards and strategy in terms of theoretical underpinnings and empirical findings, our review provides insights on 
previous research contributions illustrating the way in which the literature evolved, highlighting implications for both scholars and practitioners, and suggesting avenues for future research. In particular, our results highlight two important trends in literature on boards and strategy.

First, our findings illustrate that research on boards of directors and strategy developed from normative and structural approaches to behavioral and cognitive approaches (see figures 3 and 4). While early studies mainly discussed the desirability of board strategic involvement (period 1) and used 'input-output approaches' (period 2), a more recent strand of research posits boards as decision-making groups whose internal processes and external context should be better understood (e.g. Forbes and Milliken, 1999; Huse, 2005; McNulty and Pettigrew, 1999; Ravasi and Zattoni, 2006). This evolution is in line with the general shift in strategic management from studying 'strategy as content' to understanding 'strategy as process and context' (cf. Pettigrew et al., 2002).

Second, our results highlight that research questions, theories, settings and sources of data interact and influence our insights about the relationship between boards and strategy (see table 3). On the one hand, most empirical studies analyze US companies, refer to agency theory, examine the role of boards with regard to specific outcomes, and use archival data as main source of data. On the other hand, a relatively limited number of studies analyze non-US companies, define board strategic involvement as boards' participation in decision-making, and use qualitative methods (cf. Deutsch, 2005).

\section{Theoretical Implications}

Our study has several scholarly implications and highlights avenues for future research. First, our results reveal the need to understand the role of context at multiple levels as (i) most of the contemporary wisdom originates from US-samples of large public companies and (ii) 
comparative corporate governance studies are sparse (see figure 3). As a result, the impact of the national setting (e.g. the legal system, culture and economic conditions) and firm characteristics (e.g. the ownership structure, board structure, firm performance and life-cycle) on the relationship between boards and strategy is not fully understood (Aguilera and Cuervo-Cazurro, 2004; Ravasi and Zattoni, 2006; Hambrick, Van Werder and Zajac, 2008). For example, as the majority of studies referring to agency theory used US samples and 'input-outcome approaches', the application of agency theory to strategic decision-making processes in different national contexts may lead to the discovery of new theoretical and empirical issues (Peck and Ruigrok, 2000). Furthermore, the growing number of studies that define board strategic involvement as participation in strategic decision-making may stimulate more dynamic theories and promote research designs explicitly investigating the changing contributions of boards of directors over time (cf. Ravasi and Zattoni, 2006). In sum, multi-level approaches and international comparative corporate governance studies may contribute to the development of a better understanding of interactions between macro, meso and micro dynamics and how these forces jointly shape the relationship between boards of directors and strategy (Volberda et al., 2001; Volberda and Lewin, 2003; Hambrick et al., 2008).

Second, our results highlight the number and variety of theoretical perspectives and inconclusive empirical findings. More recently, scholars emphasized the need to go beyond structuralism and to examine board processes, board behavior and directors' cognition. This movement encourages scholars to investigate what boards and their members actually do, think and/or perceive (Pettigrew, 1992; Lawrence, 1997; Forbes and Milliken, 1999). Although our literature review shows an increasing interest to these topics, the number of studies in this area is still rather limited. Given the importance of understanding politics and bargaining processes between key actors (cf. Bradshaw-Cambell and Murray, 1991; Ravasi and Zattoni, 2006; Parker, 
2007) and the impact of overlapping and conflicting preferences within and between groups of actors (Hambrick et al., 2008), a considerable amount of research remains to be done in this area in order to clarify and improve our understanding of the board of directors' contribution to strategy-making. For example, future studies should investigate the interaction between large shareholders, board members and top management teams inside and outside board meetings (Useem and Zelleke, 2006). To reach this purpose, governance scholars are encouraged to open the black box of board research developing longitudinal studies aimed at exploring processes over an extensive time period and collecting primary data using interviews, surveys and direct observation techniques (Pettigrew et al., 2002; Huse, 2005).

\section{Practical Implications}

Our empirical findings have also implications for practitioners. First, the increasing attention in boards' contribution to strategy echoes a movement towards more board strategic involvement. Interestingly, this development seems to be conflicting with principles from agency theory that consider decision control as the primary role of boards of directors (cf. Fama and Jensen, 1983). Based on principles from agency theory, governance recommendations and best practices have generally encouraged independence and formality between independent directors and executive directors (Huse, 1994; Hamel, Van Wijk and Van Rooij, 1998; Sundaramurthy and Lewis, 2003). This view has been reinforced after each wave of corporate governance scandals, as reform initiatives (such as SOX, EU directives and national corporate governance codes) have generally emphasized board control and board independence as key mechanisms to ensure corporate accountability (Daily et al., 2003: Enrione et al., 2006). However, clearly separating decision control from decision manage-ment might pose a serious threat on a board's ability to perform its strategic role (Bezemer et al., 2007). Scholars have highlighted that the maintenance of openness, 
pro-activeness and a focus on joint value creation are important antecedents of the board's contribution to the strategic decision-making process (Zona and Zattoni, 2007). Moreover, an effective contribution of board members to strategy requires both (i) an adequate composition and structure, and (ii) well-organized internal processes (Minichilli, Zattoni and Zona, 2009). Furthermore, the introduction of governance practices, such as board induction programs and annual board reviews, may contribute to an increased awareness of the expected contribution of boards to strategy (Huse, 2005). In sum, an increase in the directors' awareness of their strategic function should be associated to a higher consideration from regulators: board composition and processes should be designed to allow all members of the board to contribute to strategic decision-making (Roberts, McNulty and Stiles, 2005).

Second, practitioners should be aware that most of the contemporary wisdom originates from a limited set of empirical contexts. As there may be important differences across contexts in terms of role expectations, board structures and actors, practitioners should be careful in applying practices in their own national context (Bamberg, 2008; Hambrick et al., 2008). The witnessed theoretical and empirical pluralism in the board-strategy literature is supportive in this respect.

\section{Limitations}

Our literature review has several limitations. First, in this review only 81 journals in the management domain were included. There could be further research potential in investigating to what extent journals in other research fields (e.g. most notably finance, accounting and law) have contributed to research on boards and strategy. Second, in this study we solely focused on published articles which explicitly mentioned the search terms director or board together with strateg* in their title, abstract and/or key words. By choosing this exploratory approach, one risks missing important papers that do not claim to be in this domain explicitly and/or refer to strategic 
content directly. Future studies could examine to what extent our findings hold when a broader definition is employed (i.e. governance and strateg*). Third, as a result of the above choices, leading books on the topic were not included in our statistical analysis (e.g. Demb and Neubauer, 1992; Conger et al., 2001; Stiles and Taylor, 2002; Charan, 2005; Leblanc and Gillies, 2005; Huse, 2007). Future studies could assess how other types of publication (e.g. academic books and consultancy reports) have contributed to the development of the board-strategy field. However, we believe that also this limitation should not be overemphasized as our analysis includes both academic and practitioners journal.

\section{CONCLUSION}

Our review of the literature on boards and strategy revealed that research on the contribution of boards of directors to strategy has rapidly developed and expanded in the last four decades. Several changes are observable across different periods in terms of the questions addressed and the methods applied. The growing attention witnessed in this review can be ascribed both to new challenges companies face in multiple contexts, and to the theoretical advancements in the fields of strategic management and corporate governance. Nevertheless, the proliferation of studies and the increasing call for more contributions have not provided a clear answer to the question of how boards of directors contribute to strategy. Despite all the endeavors undertaken in the past, we highlight that the debate on boards and strategy still provides a very promising and challenging research agenda. Corporate governance scholars are encouraged to open the black box of board research in order to develop a better understanding of the interactions between macro, meso and micro dynamics, and how these forces jointly shape the relationship between boards of directors and strategy. 


\section{REFERENCES}

Aguilera, R. V. and Cuervo-Cazurra, A. (2004) Codes of Good Governance Worldwide: What is the Trigger?, Organization Studies, 25: 415-443.

Aguilera, R. V., Filatotchev, I., Gospel, H. and Jackson, G. (2008) An Organizational Approach to Comparative Corporate Governance: Costs, Contingencies, and Complementarities, Organization Science, 19: 475-492.

Andrews, K. (1980) Directors' Responsibility for Corporate Strategy, Harvard Business Review, November-December, 112-119.

Andrews, K. (1981a) Replaying the Board's Role in Formulating Strategy, Harvard Business Review, May-June, 18-26.

Andrews, K. (1981b) Corporate strategy as a vital function of the board, Harvard Business Review, November-December, 174-184.

Arthaud-Day, M. L., Certo, S., Dalton, C. M. and Dalton, D. R. (2006) A Changing of the Guard: Executive and Director Turnover following Corporate Financial Restatements, Academy of Management Journal, 49: 1119-1136.

Bamberg, P., (2008) Beyond Contextualization-Using Context Theories to Narrow the Micro-Macro Gap in Management Research, Academy of Management Journal, 51 (5): 839-847.

Baysinger, B. and Hoskisson, R. E. (1990) The Composition of Boards of Directors and Strategic Control: Effects on Corporate Strategy, Academy of Management Review, 15: 72-87.

Baysinger, B., Kosnik, R. D. and Turk, T. A. (1991) Effects of Board and Ownership Structure on Corporate R\&D Strategy. Academy of Management Journal, 34: 205-214.

Bergh, D. D. (1995) Size and Relatedness of Units Sold: An Agency Theory and Resource-Based Perspective, Strategic Management Journal, 16: 221-239.

Bezemer, P., Maassen, G. F., Van den Bosch, F. A. J. and Volberda, H. W. (2007) Investigating the Development of the Internal and External Service Task of Non-Executive Directors: The case of the Netherlands (1997-2005), Corporate Governance: an International Review, 15: 1119-1130.

Bonn, I. and Fisher, J. (2005) Corporate Governance and Business Ethics: Insights from the Strategic Planning Experience, Corporate Governance: an International Review, 13: 230-238.

Boyd, B. K. (1990) Corporate linkages and Organizational Environment: A test of the Resource Dependence Model, Strategic Management Journal, 11: 419-430.

Boyd, B. K. (1994) Board Control and CEO Compensation, Strategic Management Journal, 15: 335-344. Bradshaw-Camball, P. and Murray, V. V. (1991) Illusions and Other Games: A Trifocal View of Organizational Politics, Organization Science, 2: 379-398.

Carpenter, M. A. and Westphal, J. D. (2001) The Strategic Context of External Network Ties: Examining the Impact of Director Appointments on Board Involvement in Strategic Decision Making, Academy of Management Journal, 44: 639-660.

Charan, R. (1998) Boards at Work: How Corporate Boards Create Competitive Advantage. San Francisco: Jossey-Bass Publishers. 
Clendenin, W. D. (1972) Company Presidents look at the Board of Directors, California Management Review, Spring, 60-66.

Coffee, J. C. (2005) Gatekeepers: the Profession and Corporate Governance. Oxford: Oxford University Press.

Coffey, A. and Atkinson, P. (1996) Making Sense of Qualitative Data Complementary Research Strategies. Thousand Oaks, CA: Sage.

Cohen, J. (1960) A Coefficient of Agreement for Nominal Scales, Educational and Psychological Measurement, 20: 37-46.

Conger, J. A., Lawler, E. E. and Finegold, D. L. (2001) Corporate Boards. New Strategies for adding value at the Top. San Francisco: Jossey-Bass Publishers.

Daily, C. M. (1995) The Relationship between Board Composition and Leadership Structure and Bankruptcy Reorganization Outcomes, Journal of Management, 21: 1041-1056.

Daily, C. M., Dalton, D. R. and Cannella, A. (2003) Corporate Governance: Decades of Dialogue and Data, Academy of Management Review, 28: 371-382.

Dalton, D. R., Daily, C. M., Ellstrand, A. E. and Johnson, J. L. (1998) Meta-Analytic Reviews of Board Composition, Leadership Structure and Financial Performance, Strategic Management Journal, 19: 269-290.

Datta, D. K., Rajagopalan, N. and Zhang, Y. (2003) New CEO Openness to Change and Strategic Persistence: The Moderating Role of Industry Characteristics, British Journal of Management, 14: 101-114.

D'Aveni, R. A. and MacMillan, I. C. (1994) Crisis and the Content of Managerial Communications: a Study of the Focus of Attention of Top Managers in Surviving and Failing Firms, Administrative Science Quarterly, 35: 643-657.

Davis, G. F. (1991) Agents without Principles? The Spread of the Poison Pill through the Intercorporate Network, Administrative Science Quarterly, 36: 583-613.

Davis, J. H., Schoorman, D. F. and Donaldson, L. (1997) Toward a Stewardship Theory of Management, Academy of Management Review, 22: 20-47.

Demb, A. and Neubauer, F. (1992) The Corporate Board, Oxford: Oxford University Press.

Deutsch, Y. (2005) The Impact of Board Composition on Firms' Critical Decisions: A Meta-Analytic Review, Journal of Management, 31: 424-444.

Dewey, M. E. (1983) Coefficients of Agreement, British Journal of Psychiatry, 143: 487-489.

Eisenhardt, K. M. (1989) Agency Theory: An Assessment and Review, Academy of Management Review, 14: 57-74.

Enrione, A., Mazza, C. and Zerboni, F. (2006) Institutionalizing Codes of Governance, American Behavioral Scientist, 49: 961-973.

Fama, E. and Jensen, M. C. (1983) Separation of Ownership and Control, Journal of Law and Economics, 26: 301-325.

Felton, S. M. (1979) To What Extent Should a Company's Outside Directors Be Involved in Setting the Future Course of a Company?, Harvard Business Review, July-August, 20-27. 
Fiegener, M. K. (2005), Determinants of Board participation in the Strategic Decisions of Small Corporations, Entrepreneurship Theory and Practice, September, 627-652.

Filatotchev, I. and Toms, S. (2003) Corporate Governance, Strategy and Survival in a Declining Industry: A Study of UK Cotton Textile Companies, Journal of Management Studies, 40: 895-920.

Forbes, D. and Milliken, F. J. (1999) Cognition and Corporate Governance: Understanding Boards of Directors as Strategic Decision-Making Groups, Academy of Management Review, 24: 489-505.

Fried, V. H., Burton, G. D. and Hisrich, R. D. (1998) Strategy and the Board of Directors in Venture Capital-Backed Firms, Journal of Business Venturing, 13: 493-503.

Fried, V. D. and Hisrich, R. D. (1995) The Venture Capitalist: A Relationship Investor, California Management Review, Winter, 101-113.

Fulghieri, P. and Hodrick, L. S. (2006) Synergies and Internal Agency Conflicts: The Double-Edged Sword of Mergers, Journal of Economics and Management Strategy, 15: 549-576.

Golden, B. R. and Zajac, E. J. (2001) When Will Boards Influence Strategy? Inclination x Power = Strategic Change, Strategic Management Journal, 22: 1087-1111.

Goodstein, J. and Boeker, W. (1992) Turbulence at the Top: a New Perspective on Governance Structure Changes and Strategic Change, Academy of Management Journal, 34: 306-330.

Goodstein, J., Gautam, K. and Boeker, W. (1994) The Effects of Board Size and Diversity on Strategic Change, Strategic Management Journal, 15: 241-250.

Grossman, W. and Cannella, A. (2006) The Impact of Strategic Persistence on Executive Compensation, Journal of Management, 32: 257-278.

Gulati, R. and Westphal, J. D. (1999) Cooperative or Controlling? The Effects of CEO-Board Relations and the Content of Interlocks on the Formation of Joint-Ventures, Administrative Science Quarterly, 44: 473-506.

Hambrick, D. C., Von Werder, A. and Zajac, E. J. (2008) New Directions in Corporate Governance Research, Organization Science, 19: 381-385.

Hamel, J. A. Van, Wijk, H. E. Van, Rooij, A. J. H. De and Bruel, M. (1998). Boardroom Dynamics: Lessons in Governance, Corporate Governance: An International Review, 6: 193-201

Harrison, J. R. (1987). The Strategic Use of Corporate Board Committees, California Management Review, Fall, 109-126.

Haunschild, P. R. (1993) Interorganizational Imitations: The impact of Interlocks on Corporate Acquisitions Activity, Administrative Science Quarterly, 38: 564-592.

Haunschild, P. R. and Beckman, C. M. (1998) When do Interlocks Matter?: Alternate Sources of Information and Interlock Influence, Administrative Science Quarterly, 43:815 844.

Hayward, M. L. A. and Hambrick, D. C. (1997) Explaining the Premium Paid for Large Acquisitions: Evidence of CEO Hubris, Administrative Science Quarterly, 42: 103-127.

Heller, J. R. and Milton, F. (1972) The Board of Directors: Legalistic Anachronism or Vital Force, California Management Review, Spring, 24-30.

Hendry, K. and Kiel, G. C. (2004) The Role of the Board in Firm Strategy: Integrating Agency and Organizational Control Perspectives. Corporate Governance: An International Review, 12: 500-520. 
Heracleous, L. (2001) What is the Impact of Corporate Governance on Organizational Performance? Corporate Governance: An International Review, 9, 165-173.

Herman, C. (1981) Corporate Power and Corporate Control. Oxford: Oxford Press.

Hillman, A. J. (2005) Politicians on the Board of Directors: Do Connections affect the Bottom Line? Journal of Management, 31: 464-481

Hillman, A. J., Cannella, A. and Paetzold, R. L. (2000) The Resource Dependence Role of Corporate Directors: Strategic Adaption of Board Composition in Response to Environmental Change, Journal of Management Studies, 37: 235-256.

Hillman, A. J. and Dalziel, T. (2003) Boards of Directors and Firm Performance: Integrating Agency and Resource Dependence Perspectives, Academy of Management Review, 28: 383-396.

Hitt, M. A., Harrison, J, S. and Ireland, D. R. (2001) Mergers and Acquisitions: a guide to value creating for stakeholders, Oxford University Press, New York.

Hoskisson, R. E., Hitt, M. A., Johnson, R. A. and Grossman, W. (2002) Conflicting Voices: The Effects of Institutional Ownership Heterogeneity and Internal Governance on Corporate Innovation Strategies, Academy of Management Journal, 45: 697-716.

Hoskisson, R. E. and Turk, T. A. (1990) Corporate Restructuring: Governance and Control Limits of the Internal Capital Market, Academy of Management Review, 15: 459-477.

Huse, M. (1994) Board-Management Relations in Small Firms: The Paradox of Simultaneous Independence and Interdependence, Small Business Economics, 6: 55-72.

Huse, M. (2005) Accountability and Creating Accountability: a Framework for Exploring Behavioral Perspectives of Corporate Governance, British Journal of Management, 16: 65-79.

Huse, M. (2007) Boards, Governance and Value Creation. Cambridge: Cambridge University Press.

Huse, M, Minichilli, A. and Shoning, M. (2005) Corporate Boards as Assets for Operating in New Europe. The Value of Process-Oriented Boardroom Dynamics, Organizational Dynamics, 34: 285-297.

Ingley, C. and Van Der Walt, N. (2005) Do Board Processes influence Director and Board Performance? Statutory and Performance Implications, Corporate Governance: An International Review, 13: 632659.

Insch, G. S., Moore, J. E. and Murphy, L. D. (1996) Content analysis in leadership research: examples, procedures, and suggestions for future use, Leadership Quarterly, 8: 1-25.

Jensen, M. C. (1993) The Modern Industrial Revolution, Exit, and the Failure of Internal Control Systems, The Journal of Finance, 48: 831-882.

Jensen, M. C. and Meckling, W. (1976) Theory of the Firm: Managerial Behavior, Agency Costs and Ownership Structure, Journal of Financial Economics, 3: 305-360.

Jensen, M. C. and Zajac, E. J. (2004) Corporate Elites and Corporate Strategy: How Demographic Preferences and Structural Position Shape the Scope of the Firm, Strategic Management Journal, 25: 507-524.

Johnson, J. L., Daily, C. M. and Ellstrand, A. E. (1996) Boards of Directors: A Review and Research Agenda, Journal of Management, 22: 409-438. 
Johnson, R. A., Hoskisson, R. E: and Hitt, M. A. (1993). Board of Director Involvement in Restructuring: the Effects of Board versus Managerial Controls and Characteristics, Strategic Management Journal, 14: $33-50$.

Judge, W. Q. and Zeithaml, C.P. (1992) Institutional and Strategic Choice Perspectives on Board Involvement in the Strategic Decision Process, Academy of Management Journal, 35: 766-794.

Judge, W. Q. and Dobbins, G.H. (1995) Antecedents and Effects of Outside Director's Awareness of CEO Decision Style, Journal of Management, 21: 43-64.

Keenan, J. (2004) Corporate Governance in UK/USA Boardrooms, Corporate Governance: an International Review, 12: 172- 176.

Kiel, G. C. and Nicholson, G. J. (2003) Board Composition and Corporate Performance: How the Australian Experience Informs Contrasting Theories of Corporate Governance, Corporate Governance: An International Review, 11: 189- 207.

Kuhn, T. S. (1962) The Structure of Scientific Revolutions, Chicago: University of Chicago Press.

Kor, Y. Y. (2006) Direct and Interaction Effects of Top Management Team and Board Compositions on R\&D Investment Strategies, Strategic Management Journal, 27: 1081-1099.

Kosnik, R.D. (1987) Greenmail: A Study of Board Performance in Corporate Governance. Administrative Science Quarterly, 32: 163-185.

Kosnik, R.D. (1990) Effects of Board Demography and Directors' Incentives on Corporate Greenmail Decisions, Academy of Management Journal, 33: 129-150.

Krippendorff, K. (2005) Content Analysis: An Introduction to its Methodology”, Second Edition, Newbury Park CA: Sage.

Lang, J. R. and Lockhart, D. E. (1990) Increased Environmental Uncertainty and Changes in Board Linkages Patterns, Academy of Management Journal, 33: 106-128.

Lawrence, B. (1997) The Black Box of Organizational Demography, Organization Science, 8: 1-22.

Leblanc, R. and Gillies, J. (2005) Inside the Board Room. Ontario: John Wiley \& Sons Ltd.

Lee, T. W. (1999) Using Qualitative Methods in Organizational Research. Thousand Oaks, CA: Sage.

Long, T., Dulewicz, V. and Gay, K. (2005) The Role of the Non Executive Director: Findings of an Empirical Investigation into the Differences between Listed and Unlisted UK Boards, Corporate Governance: An International Review, 13: 667-679.

Lorsch, J. (1986) Managing Culture: The Invisible Barrier to Strategic Change, California Management Review, 28: 95-109.

Lorsch, J. and MacIver, E. (1989) Pawns or Potentates. The Reality of America's Corporate Boards. Boston: HBS Press.

Maassen, G. F. and Van den Bosch, F. A. J. (1999) On the supposed independence of Two-Tier Boards: Formal Structure and Reality in the Netherlands, Corporate Governance: An International Review, 7: 31-37.

Mace, M. (1971) Directors: Myth and reality. Boston: Harvard Business School Press. Mace, M. (1976) Attracting new directors, Harvard Business Review, September-October, 46-51. 
Machin, J. L. H. and Wilson, L. S. (1979) Closing the Gap between Planning and Control, Long Range Planning, 12: 16-33.

McNulty, T. and Pettigrew, A. M. (1999) Strategists on Boards, Organization Studies, 20: 47- 74.

Minichilli, A., Zattoni, A., and Zona, F. (2009) Making boards effective: An empirical examination of board task performance, British Journal of Management, 20(1): 55-74.

Mizruchi, M. S. (1983) Who controls Whom? An Examination of the Relation Between Management and Boards of Directors in large American Corporations, Academy of Management Review, 8: 426-435.

Monks, R. and Minow, N. (2008) Corporate Governance. Wiley: London.

Mueller, F., Sillince, J., Harvey, C. and Howorth, C. (2003) A Rounded Picture is What We Need: Rhetorical Strategies, Arguments, and the Negotiation of Change in a UK Hospital Trust, Organization Studies, 25: 75-93.

Muth, M. M. and Donaldson, L. (1998) Stewardship Theory and Board Structure: A Contingency Approach, Corporate Governance: An International Review, 6, 5-29.

Parker, L. D. (2007) Boardroom Strategizing in Professional Associations: Processual and Institutional Perspectives, Journal of Management Studies, 44: 1454-1481.

Pearce, J. A. and Zahra S. A. (1992) Board Composition from a Strategic Contingency Perspective, Journal of Management Studies, 29: 411-439.

Peck, S. I. and Ruigrok, W. (2000) Hiding behind the Flag? Prospects for Change in German Corporate Governance, European Management Journal, 18: 420-430.

Pettigrew, A. M. (1992) On Studying Managerial Elites, Strategic Management Journal: 13, 163-182.

Pettigrew A. M., Thomas H. and Whittington R. (Eds.) (2002) The Handbook of Strategy and Management. London: Sage.

Pfeffer, J. (1972) Size and Composition of Corporate Boards of Directors: The Organization and Its Environment, Administrative Science Quarterly, 17: 218-228.

Pfeffer, J. (1973). Size, Composition and the Function of Hospital Boards of Directors: The Organization and its Environment, Administrative Science Quarterly, 18: 349-366.

Pfeffer, J. and Salancik, G. R. (1978) The External Control of Organizations: A Resource Dependency Perspective. New York: Harper and Row.

Pye, A. and Camm G. (2003) Non-Executive Directors: Moving beyond the "One Size fits-all View", Journal of General Management, 28: 52-72.

Ravasi, D. and Zattoni, A. (2006) Exploring the Political Side of Board Involvement in Strategy: A Study of Mixed-Ownership Institutions, Journal of Management Studies, 48: 1672- 1704.

Rindova, V. (1999) What Corporate Boards Have To Do With Strategy: A Cognitive Perspective, Journal of Management Studies, 36: 953- 975.

Roberts, J. (2002) Building the Complementary Board: The Work of the PLC Chairman, Long Range Planning, 35: 493-520.

Roberts, J., McNulty, T. and Stiles P. (2005) Beyond agency conceptions of the work of the non-executive director: Creating accountability in the boardroom, British Journal of Management, 16, 5-26. 
Rosenstein, J. (1987) Why don't US Boards get more Involved in Strategy?, Long Range Planning, 20: 3034.

Ruigrok, W., Peck, S., and Keller, P. (2006) Board Characteristics and Involvement in the Strategic decision-making: Evidence from Swiss Companies, Journal of Management Studies, 43: 1201-1226.

Sanders, W. M. and Carpenter, M. A. (1998) Internationalization and Firm Governance: The Roles of CEO compensation, Top Team composition and Board Structure, Academy of Management Journal, 14: $158-178$.

Schmidt, S. and Bauer, M. (2006) Strategic Governance: How to Assess Board Effectiveness in Guiding Strategy Execution, Corporate Governance An International Review, 14: 13- 23.

Seglen, P. O. (1994) Causal Relationship between Article Citedness and Journal Impact Factor, Journal of the America Society for Information Science, 45: 1-11.

Sheppard, J.P. (1994) Strategy and Bankruptcy: An Exploration into Organizational Death, Journal of Management, 20: 795-833.

Sheridan, L., Jones, E. and Marston, C. (2006) Corporate Governance Codes and the Supply of Corporate Information in the UK, Corporate Governance: An International Review, 12: 489-499.

Stiles, P. (2001) The Impact of the Board on Strategy: An Empirical Examination, Journal of Management Studies, 38: 627-650.

Stiles, P. and Taylor, B. (1996) The Strategic Role of the Board, Corporate Governance: An International Review, 4: 3-10.

Stiles, P. and Taylor, B. (2002) Boards at Work: How Directors view their Roles and Responsibilities. New York: Oxford University Press Inc.

Sundaramurthy, G. and Lewis, M. (2003) Control and Collaboration: Paradoxes of Governance, Academy of Management Review, 28: 397-415.

Tihanyi, L., Johnson, R. A., Hoskisson, R. E. and Hitt, M. A. (2003) Institutional Ownership Differences and International Diversification: The Effects of Boards of Directors and Technological Opportunity, Academy of Management Journal, 46: 195-211.

Tricker, B. (1984) Corporate Governance. Oxford: Blackwell Publishing Limited.

Useem, M. (2003) Corporate Governance is Directors Making Decisions: Reforming the Outward Foundations for Inside Decision Making, Journal of Management and Governance, 7: 241-253.

Useem, M. and Zelleke, A. (2006) Oversight and Delegation in Corporate Governance: Deciding what the Board should decide, Corporate Governance: An International Review, 14: 2-12.

Vance, J. O. (1979) The Care and Feeding of the Board of Directors, California Management Review, Summer, 29-34.

Van den Heuvel, J., Van Gils, A. and Voordeckers, W. (2005) Board Roles in Small and Medium Sized Family Businesses, Corporate Governance: An International Review, 13: 467-483.

Volberda, H. W. and Lewin, A.Y. (2003) Co-evolutionary Dynamics Within and Between Firms: From Evolution to Co-evolution, Journal of Management Studies, 40: 2111-2136.

Volberda, H. W., Baden-Fuller, C. and Van den Bosch, F. A. J. (2001) Mastering strategic Renewal: Mobilizing Renewal Journeys in Multi-Unit Firms, Long Range Planning, 34, 159-178. 
Volberda, H. W. and Elfring, T. (eds.) (2001) Rethinking strategy. London: SAGE.

Westphal, J. D. (1998) Board Games: How CEOs Adapt to Increases in Structural Board Independence from Management, Administrative Science Quarterly, 43: 511-537.

Westphal, J. D. and Fredrickson, J. W. (2001) Who Directs Strategic Change? Director Experience, the Election of New CEOs, and Change in Corporate Strategy, Strategic Management Journal, 22: 11131137.

Wommack, W. W. (1979) The Board's Most Important Function, Harvard Business Review, 57: 48-55.

Yawson, A. (2006) Evaluating the Characteristics of Corporate Boards Associated with Layoff Decisions, Corporate Governance: An International Review, 14: 75- 85.

Yoshikawa, T. and Phan, P. H. (2005) The Effects of Ownership and Capital Structure on Board Composition and Strategic Diversification in Japanese Corporations, Corporate Governance: An International Review, 13: 303-312.

Zahra, S. A. (1990) Increasing the Board's Involvement in Strategy, Long Range Planning, 23: 109-117.

Zahra, S. A. (1996) Governance, Ownership, and Corporate Entrepreneurship: the Moderating Impact of Industry Technological Opportunities, Academy of Management Journal, 39: 1713-1735.

Zahra, S. A. and Filatotchev, I. (2004) Governance of the Entrepreneurial Threshold Firm: A Knowledgebased Perspective, Journal of Management Studies, 41: 885-897.

Zahra, S. A., Neubaum, D. and Huse, M. (2000) Entrepreneurship in Medium-Size Companies: Exploring the Effects of Ownership and Governance Systems, Journal of Management, 26: 947-976.

Zahra, S. A. and Pearce, J. (1989) Boards of Directors and Corporate Financial Performance: A Review and Integrative Model, Journal of Management, 15: 291-334.

Zahra, S. A., and Pearce, J. (1990) Determinants of Board Directors' Strategic Involvement, European Management Journal, 8: 164-173.

Zattoni, A. and Cuomo F. (2008) Why Adopt Codes of Good Governance? A Comparison of Institutional and Efficiency Perspectives, Corporate Governance: An International Review, 16: 1-15.

Zona, F. and Zattoni, A. (2007) Beyond the Black Box of Demography: Board Processes and Task Effectiveness within Italian Firms, Corporate Governance: An International Review, 15: 852-867. 
Figure 1: Historical Development Research on Boards and Strategy

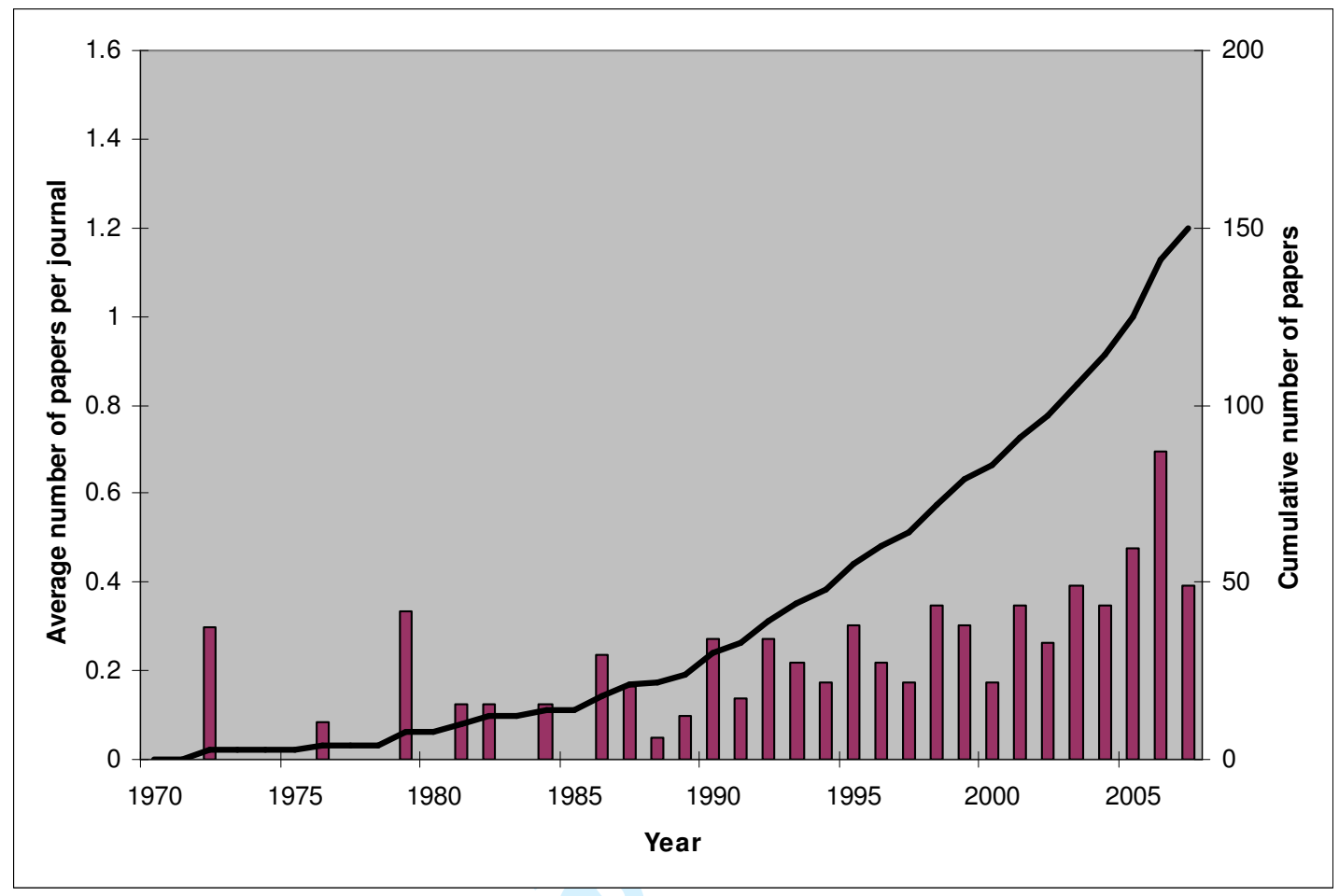

29

30

31

32

33

34

35

36

37

38

39

40

41

42

43

44

45

46

47

48

49

50

51

52

53

54

55

56

57

58

59

60 
Figure 2: Overview of Journals with Included Publications per Time Period

\begin{tabular}{|l|c|c|c|c|}
\hline & $\mathbf{1 9 7 2 - 1 9 8 9}$ & $\mathbf{1 9 9 0 - 2 0 0 0}$ & $\mathbf{2 0 0 1 - 2 0 0 7}$ & overall \\
\hline Corporate Governance: An International Review & N/A & 4 & 20 & 24 \\
\hline Strategic Management Journal & 2 & 7 & 7 & 16 \\
\hline Long Range Planning & 8 & 6 & 2 & 16 \\
\hline Academy of Management Journal & 1 & 8 & 5 & 14 \\
\hline Harvard Business Review & 5 & 6 & 2 & 13 \\
\hline Journal of Management & 1 & 6 & 4 & 11 \\
\hline Administrative Science Quarterly & 0 & 7 & 3 & 10 \\
\hline Journal of Management Studies & 0 & 4 & 6 & 10 \\
\hline California Management Review & 6 & 1 & 1 & 8 \\
\hline Academy of Management Executive & 0 & 2 & 4 & 6 \\
\hline Academy of Management Review & 0 & 3 & 0 & 3 \\
\hline Organizational Dynamics & 0 & 0 & 3 & 3 \\
\hline Organization Studies & 0 & 1 & 1 & 2 \\
\hline Organization Science & N/A & 2 & 0 & 2 \\
\hline Journal of Small Business Management & 0 & 0 & 2 & 2 \\
\hline British Journal of Management & N/A & 1 & 1 & 2 \\
\hline International Journal of Technology Management & 0 & 1 & 1 & 2 \\
\hline Management Science & 0 & 0 & 1 & 1 \\
\hline Journal of International Business & 1 & 0 & 0 & 1 \\
\hline Decision Science & 0 & 1 & 0 & 1 \\
\hline Tourism Management & 0 & 0 & 1 & 1 \\
\hline Journal of Organizational Change Management & 0 & 0 & 1 & 1 \\
\hline Service Industries Journal & 0 & 0 & 1 & 1 \\
\hline
\end{tabular}

*N/A: Journal was founded after this particular time period 
Figure 3: Descriptives and Interactions of Topics, Theories, Settings and Data Sources**

\begin{tabular}{|c|c|c|c|c|c|c|}
\hline & \multicolumn{4}{|c|}{ Empirical Papers (n=114; 76\%) } & \multirow{2}{*}{$\begin{array}{c}\text { Theoretical } \\
\text { Papers } \\
(\mathbf{n}=\mathbf{3 6} ; 24 \%)\end{array}$} & \multirow{2}{*}{ Overall $(n=150)$} \\
\hline & $\begin{array}{c}\text { US context } \\
(n=72 ; 62 \%)\end{array}$ & $\begin{array}{c}\text { Multiple contexts } \\
\text { (including US) } \\
(\mathrm{n}=5 ; 4 \%)\end{array}$ & 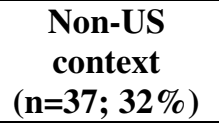 & Total & & \\
\hline $\begin{array}{l}\text { Main Research Topic*: } \\
\text { Determinants of board strategic involvement } \\
\text { Consequences of board strategic involvement } \\
\text { Boards' participation in strategic decision making } \\
\text { Desirability of strategic involvement (normative) } \\
\text { Total }\end{array}$ & $\begin{array}{l}26(36 \%) \\
21(29 \%) \\
11(15 \%) \\
14(19 \%) \\
72(100 \%) \\
\end{array}$ & $\begin{array}{c}0(0 \%) \\
1(20 \%) \\
1(20 \%) \\
3(60 \%) \\
5(100 \%) \\
\end{array}$ & $\begin{array}{c}8(22 \%) \\
10(27 \%) \\
14(38 \%) \\
5(14 \%) \\
37(100 \%) \\
\end{array}$ & $\begin{array}{c}34(30 \%) \\
32(28 \%) \\
26(23 \%) \\
22(19 \%) \\
114(100 \%) \\
\end{array}$ & $\begin{array}{c}2(6 \%) \\
4(11 \%) \\
11(31 \%) \\
19(53 \%) \\
36(100 \%) \\
\end{array}$ & $\begin{array}{c}36(24 \%) \\
36(24 \%) \\
37(25 \%) \\
41(27 \%) \\
150(100 \%) \\
\end{array}$ \\
\hline $\begin{array}{l}\text { Use of Theories*: } \\
\text { Articles referring to agency theory } \\
\text { Articles referring to multiple lenses (including agency) } \\
\text { Articles solely referring to other theories or no theory } \\
\text { Total }\end{array}$ & $\begin{array}{c}18(25 \%) \\
20(28 \%) \\
34(47 \%) \\
72(100 \%) \\
\end{array}$ & $\begin{array}{c}0(0 \%) \\
0(0 \%) \\
5(100 \%) \\
5(100 \%) \\
\end{array}$ & $\begin{array}{c}3(8 \%) \\
9(24 \%) \\
25(68 \%) \\
37(100 \%) \\
\end{array}$ & $\begin{array}{c}21(18 \%) \\
29(25 \%) \\
64(56 \%) \\
114(100 \%) \\
\end{array}$ & $\begin{array}{c}6(17 \%) \\
7(19 \%) \\
23(64 \%) \\
36(100 \%) \\
\end{array}$ & $\begin{array}{c}27(18 \%) \\
36(24 \%) \\
87(58 \%) \\
150(100 \%) \\
\end{array}$ \\
\hline $\begin{array}{l}\text { Source of Data*: } \\
\text { Interviews } \\
\text { Anecdotal Evidence } \\
\text { Archival Data } \\
\text { Survey } \\
\text { Direct Observations } \\
\text { Multiple Sources } \\
\text { Total } \\
\end{array}$ & $\begin{array}{c}3(4 \%) \\
10(14 \%) \\
39(54 \%) \\
5(7 \%) \\
0(0 \%) \\
15(21 \%) \\
72(100 \%) \\
\end{array}$ & $\begin{array}{c}2(40 \%) \\
0(0 \%) \\
0(0 \%) \\
1(10 \%) \\
0(0 \%) \\
2(40 \%) \\
5(100 \%) \\
\end{array}$ & $\begin{array}{l}10(27 \%) \\
4(11 \%) \\
6(16 \%) \\
7(19 \%) \\
5(14 \%) \\
5(14 \%) \\
37(100 \%) \\
\end{array}$ & $\begin{array}{l}15(13 \%) \\
14(12 \%) \\
45(40 \%) \\
13(11 \%) \\
5(4 \%) \\
22(19 \%) \\
114(100 \%) \\
\end{array}$ & $\begin{array}{l}- \\
- \\
- \\
- \\
- \\
- \\
-\end{array}$ & $\begin{array}{l}15(13 \%) \\
14(12 \%) \\
45(40 \%) \\
13(11 \%) \\
5(4 \%) \\
22(19 \%) \\
114(100 \%)\end{array}$ \\
\hline $\begin{array}{l}\text { Definition of Board Strategic Involvement*: } \\
\text { Unspecified } \\
\text { Boards define strategy at a general level } \\
\text { Boards are responsible for specific outcomes } \\
\text { Boards participate to decision-making process } \\
\text { Total }\end{array}$ & $\begin{array}{c}21(29 \%) \\
7(10 \%) \\
37(51 \%) \\
7(10 \%) \\
72(100 \%) \\
\end{array}$ & $\begin{array}{c}1(20 \%) \\
3(60 \%) \\
1(20 \%) \\
0(0 \%) \\
5(100 \%) \\
\end{array}$ & $\begin{array}{c}9(24 \%) \\
10(27 \%) \\
9(24 \%) \\
9(24 \%) \\
37(100 \%) \\
\end{array}$ & $\begin{array}{c}31(27 \%) \\
20(18 \%) \\
47(41 \%) \\
16(14 \%) \\
114(100 \%)\end{array}$ & $\begin{array}{c}17(47 \%) \\
8(22 \%) \\
5(14 \%) \\
6(17 \%) \\
36(100 \%) \\
\end{array}$ & $\begin{array}{c}48(32 \%) \\
28(19 \%) \\
52(35 \%) \\
22(15 \%) \\
150(100 \%) \\
\end{array}$ \\
\hline
\end{tabular}

* Differences between different research settings are statistically significant at the 0.05 -level (two-tailed).

** Statistical tests show that the relationships between the main research topic, use of theories, definition of board strategic involvement and research setting are all significant at the 0.05 -level (two-tailed) 
Figure 4: Evolution of the Literature on Boards and Strategy

\begin{tabular}{|c|c|c|c|c|}
\hline & 1972-1989 & $1990-2000$ & 2001-2007 & overall \\
\hline $\begin{array}{l}\text { Summary: } \\
\text { Number of articles } \\
\text { Average number of articles per year } \\
\text { Average number of articles per journal per year }\end{array}$ & $\begin{array}{c}24 \\
1.33 \\
0.10\end{array}$ & $\begin{array}{c}59 \\
5.36 \\
0.23\end{array}$ & $\begin{array}{c}67 \\
9.57 \\
0.42\end{array}$ & $\begin{array}{l}150 \\
4.16 \\
0.20\end{array}$ \\
\hline $\begin{array}{l}\text { Type of Article } \\
\text { Conceptual } \\
\text { Empirical } \\
\text { Total } \\
\end{array}$ & $\begin{array}{c}10(42 \%) \\
14(58 \%) \\
24(100 \%)\end{array}$ & $\begin{array}{c}14(24 \%) \\
45(76 \%) \\
59(100 \%)\end{array}$ & $\begin{array}{l}12(18 \%) \\
55(82 \%) \\
67(100 \%)\end{array}$ & $\begin{array}{c}36(24 \%) \\
114(76 \%) \\
150(100 \%)\end{array}$ \\
\hline $\begin{array}{l}\text { Main Research Topic*: } \\
\text { Determinants of board strategic involvement } \\
\text { Consequences of board strategic involvement } \\
\text { Boards' participation in strategic decision making } \\
\text { Desirability of strategic involvement (normative) } \\
\text { Total }\end{array}$ & $\begin{array}{c}3(13 \%) \\
3(13 \%) \\
2(8 \%) \\
16(67 \%) \\
24(100 \%) \\
\end{array}$ & $\begin{array}{l}16(27 \%) \\
18(31 \%) \\
12(20 \%) \\
13(22 \%) \\
59(100 \%) \\
\end{array}$ & $\begin{array}{l}17(25 \%) \\
15(22 \%) \\
23(34 \%) \\
12(18 \%) \\
67(100 \%) \\
\end{array}$ & $\begin{array}{r}36(24 \%) \\
36(24 \%) \\
37(25 \%) \\
41(27 \%) \\
150(100 \%) \\
\end{array}$ \\
\hline $\begin{array}{l}\text { Use of Theories*: } \\
\text { Articles referring to agency theory } \\
\text { Articles referring to multiple lenses (including agency) } \\
\text { Articles solely referring to other theories or no theory } \\
\text { Total }\end{array}$ & $\begin{array}{c}2(8 \%) \\
1(4 \%) \\
21(88 \%) \\
24(100 \%) \\
\end{array}$ & $\begin{array}{l}13(22 \%) \\
19(32 \%) \\
27(46 \%) \\
59(100 \%) \\
\end{array}$ & $\begin{array}{l}12(18 \%) \\
16(24 \%) \\
39(58 \%) \\
67(100 \%) \\
\end{array}$ & $\begin{array}{c}27(18 \%) \\
36(24 \%) \\
87(58 \%) \\
150(100 \%) \\
\end{array}$ \\
\hline $\begin{array}{l}\text { Research Setting*: } \\
\text { Articles based on US data only } \\
\text { Articles based on multiple settings (including the US) } \\
\text { Articles based on non-US data } \\
\text { Total }\end{array}$ & $\begin{array}{c}7(50 \%) \\
4(29 \%) \\
3(21 \%) \\
14(100 \%) \\
\end{array}$ & $\begin{aligned} & 38(84 \%) \\
& 1(2 \%) \\
& 6(13 \%) \\
& 45(100 \%) \\
&\end{aligned}$ & $\begin{array}{c}27(49 \%) \\
0(0 \%) \\
28(51 \%) \\
55(100 \%)\end{array}$ & $\begin{aligned} & 72(62 \%) \\
& 5(4 \%) \\
& 37(32 \%)(100 \%) \\
& 114(\end{aligned}$ \\
\hline $\begin{array}{l}\text { Source of Data: } \\
\text { Interviews } \\
\text { Anecdotal Evidence } \\
\text { Archival Data } \\
\text { Survey } \\
\text { Direct Observations } \\
\text { Multiple Sources } \\
\text { Total }\end{array}$ & $\begin{array}{c}1(7 \%) \\
3(21 \%) \\
3(21 \%) \\
2(14 \%) \\
0(0 \%) \\
5(36 \%) \\
14(100 \%) \\
\end{array}$ & $\begin{array}{c}5(11 \%) \\
4(9 \%) \\
22(49 \%) \\
3(7 \%) \\
2(4 \%) \\
9(20 \%) \\
45(100 \%) \\
\end{array}$ & $\begin{array}{c}9(16 \%) \\
7(13 \%) \\
20(36 \%) \\
8(15 \%) \\
3(6 \%) \\
8(15 \%) \\
55(100 \%) \\
\end{array}$ & $\begin{array}{c}15(13 \%) \\
14(12 \%) \\
45(40 \%) \\
13(11 \%) \\
5(4 \%) \\
22(19 \%) \\
114(100 \%) \\
\end{array}$ \\
\hline $\begin{array}{l}\text { Definition of Board Strategic Involvement*: } \\
\text { Unspecified } \\
\text { Boards define strategy at a general level } \\
\text { Boards are responsible for specific outcomes } \\
\text { Boards participate to decision-making process } \\
\text { Total }\end{array}$ & $\begin{array}{l}11(46 \%) \\
8(33 \%) \\
3(13 \%) \\
2(8 \%) \\
24(100 \%)\end{array}$ & $\begin{array}{c}20(34 \%) \\
8(14 \%) \\
26(44 \%) \\
5(8 \%) \\
59(100 \%)\end{array}$ & $\begin{array}{l}17(25 \%) \\
12(18 \%) \\
23(34 \%) \\
15(22 \%) \\
67(100 \%)\end{array}$ & $\begin{array}{l}48(32 \%) \\
28(19 \%) \\
52(35 \%) \\
22(15 \%) \\
150(100 \%)\end{array}$ \\
\hline
\end{tabular}

* Differences between the three time periods are statistically significant at the 0.05 -level (two-tailed).

$\dagger$ Differences between the three time periods are statistically significant at the 0.10-level (two-tailed). 
Figure 5: The Evolution of Research on Board Strategic Involvement*

\begin{tabular}{|c|c|c|c|}
\hline & Time-Period 1 (1972-1989) & Time-Period 2 (1990-2000) & Time-Period 3 (2001-2007) \\
\hline Type of Paper & $\begin{array}{l}\text { Both conceptual and empirical papers give } \\
\text { initial input to the field. Early articles are } \\
\text { published in three practitioner-oriented } \\
\text { journals (i.e. HBR,LRP,CMR). }\end{array}$ & $\begin{array}{l}\text { Empirical articles gain considerable } \\
\text { attention in the literature and become by } \\
\text { far the largest category. }\end{array}$ & $\begin{array}{c}\text { Empirical articles are still gaining } \\
\text { importance, while the relative share of } \\
\text { conceptual papers has halved compared } \\
\text { to the period } 1972-1989 .\end{array}$ \\
\hline $\begin{array}{r}\text { Main Research } \\
\text { Topic }\end{array}$ & $\begin{array}{l}\text { Researchers endeavor to define to what } \\
\text { extent boards should (not) be actively } \\
\text { involved, also in the realm of strategy. }\end{array}$ & $\begin{array}{l}\text { This period is characterized by "input- } \\
\text { output" studies which aimed at exploring } \\
\text { determinants and consequences of board } \\
\text { strategic involvement. }\end{array}$ & $\begin{array}{l}\text { The focus of researchers switches to } \\
\text { boards' participation to strategic } \\
\text { decision-making, while "input-output" } \\
\text { studies remain the largest group. }\end{array}$ \\
\hline Use of Theories & $\begin{array}{l}\text { Most studies refer to other theories than } \\
\text { agency theory (for example: resource } \\
\text { dependency) or do not use a theory at all } \\
\text { (as multiple studies are practice driven). }\end{array}$ & $\begin{array}{l}\text { Agency theory becomes the most } \\
\text { commonly used framework for exploring } \\
\text { boards' contribution to strategy. }\end{array}$ & $\begin{array}{l}\text { This period is characterized by a multi- } \\
\text { theoretical approach to the board-strategy } \\
\text { debate. Agency theory is still the main } \\
\text { framework but other theories slowly gain } \\
\text { importance. }\end{array}$ \\
\hline Research Setting & $\begin{array}{l}\text { Empirical articles most often use US } \\
\text { samples or multi-country samples } \\
\text { (including the US as research setting) }\end{array}$ & $\begin{array}{l}\text { US scholars are taking the lead in the field. } \\
\text { US samples represent almost the totality of } \\
\text { empirical studies. }\end{array}$ & $\begin{array}{c}\text { European and Asian samples gain } \\
\text { importance in the debate. They equal the } \\
\text { number of published articles using US } \\
\text { samples. }\end{array}$ \\
\hline Sources of Data & $\begin{array}{l}\text { Sources of information are quite varied. } \\
\text { Anecdotes, archival data and mixed } \\
\text { methods are the most widely used. }\end{array}$ & $\begin{array}{l}\text { This period is mainly characterized by the } \\
\text { use of archival data and mixed methods. }\end{array}$ & $\begin{array}{l}\text { Sources of information are quite varied. } \\
\text { Archival data, surveys and mixed } \\
\text { methods are the most widely used. }\end{array}$ \\
\hline $\begin{array}{r}\text { Definition of } \\
\text { Board Strategic } \\
\text { Involvement }\end{array}$ & $\begin{array}{l}\text { The definition of strategic involvement is } \\
\text { ill-defined. The expected contributions of } \\
\text { board members refers to strategy in } \\
\text { general or remain rather undefined. }\end{array}$ & $\begin{array}{l}\text { Researchers start to specify board strategic } \\
\text { involvement and mainly focus on specific } \\
\text { strategic outcomes. }\end{array}$ & $\begin{array}{l}\text { A growing stream of research relates } \\
\text { boards to strategic decision making, } \\
\text { while studies referring to specific } \\
\text { strategic outcomes remain dominant }\end{array}$ \\
\hline
\end{tabular}

* The descriptives in this figure are based upon the presented numbers in figures 2 and 4. 